\title{
Hamba Tuhan sebagai Aktor Utama \\ di Era Transisi dari Specialization kepada Globalization (Eksposisi Konteks Postmodern dan Teks Efesus 5:15-21)
}

\author{
Stevri Indra Lumintang \\ Direktur Pascasarjana Sekolah Tinggi Teologi Excelius \\ stevind@gmail.com
}

\begin{abstract}
The movement of globalization caused postmoderns to "replace the modern worldview" with "postmodern worldview". That means there are massive and fundamental changes. Therefore, this transition period is a period of great change, which is not easily accepted by many people because it has caused many major problems with humanity. Globalization presses in many directions, so that nothing is lost. Globalization has made many people and organizations become voracious and ferocious. That means using the time available. Nothing is greater than God's will. The will of globalization is under God's will. This is the strong foundation of a servant of God acting as the main actor of globalization. The main role of God's servants as the main actor of globalization, namely preaching the Word.
\end{abstract}

Keywords: Transation; Specialization; Globalization; Postmodernism

\begin{abstract}
Abstrak
Gerakan globalisasi menyebabkan kaum postmodern "mengganti worldview modern" dengan "worldview postmodern". Itu artinya terjadi perubahan besar-besaran dan mendasar. Karena itu, masa peralihan ini merupakan masa perubahan besar, yang tidak mudah diterima oleh banyak orang karena telah menyebabkan banyak masalah yang besar terhadap humanistas. Globalisasi menekan ke banyak arah, sehingga tidak ada yang luput dari pengaruhnya. Globalisasi telah membuat banyak orang dan organisasi tertentu menjadi rakus dan ganas tiada ampun. Itu artinya menggunakan waktu yang ada. Tidak ada yang lebih hebat dari pada kehendak Allah. Kehendak globalisasi berada di bawah kehendak Allah. Inilah dasar yang kuat dari seorang hamba Tuhan berperan sebagai aktor utama globalisasi. Peran utama hamba Tuhan sebagai aktor utama globalisasi, yaitu memberitakan Firman.
\end{abstract}

Kata Kunci: Transisi; Specialisasi; Globalisasi; Postmodernisme 


\section{PENDAHULUAN}

Ada sejumlah pernyataan sebagai berikut ini: "Siapa cepat (instant), dia dapat; siapa dapat, dia senang; siapa yang lebih menyenangkan, dia disukai; siapa yang disukai, dia untung; siapa yang untung, dia menjadi lebih besar; siapa yang lebih besar, dia kuat; siapa yang kuat, dia menguasai; siapa yang menguasai, dia kaya; siapa yang kaya, dia mampu membeli; siapa yang mampu membeli, dia memiliki; siapa yang memiliki dia menjadi tuan; siapa yang menjadi tuan, maka yang lainnya budak". Inilah gambaran mengenai persaingan bebas di arena global yang disponsori oleh spirit globalisasi. Akibatnya, semakin suburlah praktik neo-liberalisme, neo-kapitalisme ekonomi, imperialisme dan neokolonialisme.

Alhasil, mereka yang kurang, yang sedikit, yang kecil, yang lemah, yang miskin, yang buruk menjadi budak dari mereka yang lebih, yang mayoritas, yang besar, yang kuat, yang kaya, dan yang baik rupanya (kemasan). Ini sedang terjadi! Karena itu, nilai gotong royong sedang hilang, nilai persekutuan (koinonia) sedang senyap di tengah keramaian. Nilai kebersamaan, sedang memudar. Nilai nasionalisme sedang kabur. Nilai persatuan gerejapun sudah

${ }^{1}$ Myron B. Penner, Christianity and the Postmodern Turn, (Grand Rapids: Brazos Press, 2005), 18-19. langka. Nilai kemanusiaan sedang diganti dengan nilai barang, bahkan nilai ketuhanan dipolitisasi menjadi alat kekuasaan ekonomi oleh orang beragama bahkan oleh pemimpin agama. Mengapa demikian? Jawabanya adalah karena sampai sekarang ini, masih sedang berlangsung proses peralihan (transisi) antara modernisasi (spesialisasi) kepada postmodernisasi (globalisasi).

\section{METODOLOGI PENELITIAN}

Dalam meneliti artikel ini, penulis menggunakan penelitian melalui studi pustaka.

\section{ANALISIS DAN HASIL PENELITIAN}

$\underline{\text { Transisi dari Specialisasi (Modern) menjadi }}$ Globalisasi (Postmodern)

Pada masa peralihan dari pra-modern kepada modern, gereja pun bergumul lama dengan pengaruh enlightenment (rationalism, empiricism dan idealism), ${ }^{1}$ terlebih dengan metode ilmiah dari IPTEK. Puji Tuhan, pada penghujung abad modern (abad 20), gereja menang terhadap dua pengaruh ini, namun baru saja gereja menarik nafas lega, ternyata gereja kembali berhadapan dengan pengaruh yang lebih kuat lagi. Gereja ditantang untuk bertheologia dengan cara membuang cara pikir dan hasil pikir modern, yang sangat 
menekankan kebenaran yang obyektif, outonomous, final, rasional, universal dan kekal, ${ }^{2}$ yang tertentu, detail dan atomistic (spesialisasi) menjadi kebenaran yang subyektif, perspektif, dan oceanistic (globalisasi). ${ }^{3}$

Postmodern menolak kebenaran yang real, transcendent, universal, yang pasti (certainty), final, metafisik dan metanarasi. ${ }^{4}$ Dengan demikian, melalui gerakan globalisasi, kaum postmodern "mengganti worldview modern" dengan "worldview postmodern". Itu artinya terjadi perubahan besar-besaran dan mendasar. Karena itu, masa peralihan ini merupakan masa perubahan besar, yang tidak mudah diterima oleh banyak orang karena telah menyebabkan banyak masalah yang besar terhadap humanistas.

Perubahan besar-besaran yang terjadi pada masa transisi ini membuat banyak orang kaget, terkejut, bingung, dan merasa aneh hidup di tengah-tengah hal-hal yang kelihatannya tidak masuk akal. Dahulu pada umumnya rumah dicat dengan warna putih, sekarang dengan warna-warna cerah seperti kuning, merah dan biru. Dahulu film-film

${ }^{2}$ John R. Franke, The Character of Theology: A Postconservative Evangelical Approach, (Grand Rapids: Baker Academis, 2005), 18.

${ }^{3}$ David S. Dockery, The Challenge of Postmodern: An Evangelical Engagement, (Grand Rapids: Baker Academic, 2001), 13.

${ }^{4}$ Kevin J. Vanhoozer, Postmodern Theology, (Cambridge, UK: Cambridge University Press, 2003), 11-12. yang berbauk mistis dianggap impossible, sekarang dianggap possible dan diminati. Dahulu (modern) orang tidak percaya adanya "hantu" (arwah orang mati), sekarang dijadikan tontonan di banyak channel televisi. Standar mengukur kualitas penyanyi (American dan Indonesian Idiol termasuk AFI) tidak lagi berdasarkan kualitas penyanyi (obyektif), melainkan berdasarkan kesukaan penonton (subyektif). Dahulu, pencuri/koruptor yang tertangkap merasa sangat malu sampai bunuh diri karena tidak mampu menahan rasa malu, sekarang koruptor kehilangan rasa malu (tidak tahu malu) kembali tampil di media massa seperti tidak pernah melakukan korupsi. Dahulu seorang ilmuan tentu bukanlah rohaniawan, sekarang seorang ilmuan cenderungnya adalah seorang rohaniawan juga.

Globalisasi telah mengglobalkan figure dan peran tokoh dunia pada umumnya, ${ }^{5}$ termasuk mengglobalkan peran pemimpin-pemimpin agama tertentu, mengglobalkan perusahan-perusahan tertentu dan lembaga-lembaga internasional tertentu, ${ }^{6}$ serta peran bangsa-bangsa

${ }^{5}$ Osama bin Laden, Bill Clinton dan George W. Bush, selalu menjadi fokus media internasional, sosok yang dipuji dan dihujat.

${ }^{6}$ Perusahan multinasional seperti menjadi kuat, seperti perusahaan minyak multinasional AS yang ada di banyak negara: Unocal, Amoco, Exxon dan Pennzoil; perusahaan-perusahaan tran-nasional (TNC) dan lembaga-lembaga keuangan internasional seperti World Bank (WB). 
tertentu, ${ }^{7}$ menjadi aktor utama dalam percaturan ekonomi dan politik dunia. Globaliasi, tanpa kontrol, akan menjadikan orang-orang tertentu, perusahan tertentu dan negara tertentu seperti "binatang buas" (srigala yang ganas) bagi orang, komunitas dan bangsa yang lemah ekonomi dan politik (domba). Kata kunci globalisasi ialah POWER,${ }^{8}$ maka mereka yang mampu menjalin jaringan (networks) bisnis yang cenderung dibarengi dengan jaringan politis, merekalah yang berkuasa. Mereka yang tidak tergabung dalam jaringan tersebut, akan dianggap competitor (pesaing) dan apabila mereka tidak memiliki ketahanan ekonomi dan keamanan, seperti yang sedang dialami bangsa Indonesia masa kini, maka mereka akan menjadi mangsa dalam persaingan globalisasi yang tidak kenal ampun itu.

\section{$\underline{\text { Pengertian Globalisasi }}$}

Istilah "globalisasi" itu sendiri baru menjadi popular sejak tahun 1980-an di Amerika, saat Ronald Reagen menjadi presiden tahun 1981, beliau mengambil

\footnotetext{
${ }^{7}$ Globalisasi menjadikan Amerika sebagai negara yang kuat, sehingga dijuluki sebagai negara superpower, adidaya, yang membuat negara-negara lain seolah-oleh tidak berdaya secara ekonomi dan politik dunia. El Fisgon, Menghadapi Globalisasi, (Tangerang: PT Cipta Lintas Wacana, 2004), 61

${ }^{8}$ Power relations are deeply inscribed in the very process of globalization". Researching Globalization global/executive/htm).

${ }^{9}$ Khairuddin Tadjuddin, Globalisasi (www.selaras.com).
}

langkah politik dan memenangkan pertarungan kapitalisme melawan komunisme. Sejak saat itu, dolar menguat, Amerika menarik para investor luar negeri dan perusahan-perusahannya trans-nasional atau multi-nasional. ${ }^{9}$ Pelbagai disiplin ilmu mendekati globalisasi dalam pengertiannya masing-masing, seperti komentar Alex Araujo bahwa globalisasi adalah suatu fenomena yang dapat didekati dari semua arah yang berbeda. ${ }^{10}$ Globalisasi adalah kesadaran adanya penyatuan dunia kampung global (global village) dengan teknologi transportasi dan komunikasi. ${ }^{11}$ Namun, sesungguhnya, menurut Archer, globalisasi adalah suatu cara berpikir yang baru (a new way of thinking), yaitu cara berpikir menjadi global, meninggalkan cara berpikir regional (kedaerahan). ${ }^{12}$ Alex Araujo mengartikan lebih jauh bahwa "globalization represents a way of thinking about the world and a worldview". ${ }^{13}$ Jadi, akar globalisasi adalah pada cara berpikirnya.

Cara pikir ini sebagai bagian dari modern, juga sebagai kegagalan dari modern,

${ }^{10}$ Alex Araujo, "Globalization and World Evangelism", Evangelical Dictionary of World Mission, edited by A. Scott Moreau. (Grand Rapids: Baker Books, 2000), 59.

${ }^{11}$ R. Robertson, Globalization, (London: Sage, 1992), 8.

${ }^{12}$ M. Archer, Globalization, Knowledge and Society, (London: 1990), all pages

13 Alex Araujo, "Globalization and World Evangelism”...58. 
karena itu cara pikir ini meninggalkan cara pikir modern. Inilah cara pikir postmodern. Kata kunci postmodern adalah "networking dan interdependence, cross-border transactions, free international capital flows, and more rapid and widespread diffusion of technology". ${ }^{14}$ Perubahan ini terlihat melalui peningkatan interdependence dan interaction antara orang dan perubahan di lokasi-lokasi yang terpisah. David Held menjelaskan bahwa globalisasi adalah: (1) Peralihan aktivitas sosial, politik dan ekonomi yang melintasi batas-batas wilayah dan benua. (2) Intensifikasi investasi, keuangan, migrasi, budaya antar benua. (3) Percepatan interaksi dunia melalui sistem transportasi dan komunikasi dengan kecepatan penyebaran ide, produk makanan, informasi, kota dan penduduk. 4). Percepatan dampak yang sangat kuat dari peristiwa-peristiwa yang terjadi di belahan dunia. ${ }^{15}$

\section{$\underline{\text { Karakteristik Globalisasi }}$}

Dengan demikian, globalisasi adalah proses yang kompleks, yaitu proses internasionalisasi semua bidang khususnya perdagangan dan investasi perusahaan

\footnotetext{
${ }^{14}$ IMF, World Economic Outlook, May 1997 (www.imf.org/external/np/ib/2000)

${ }^{15}$ David Held, Anthony McGrew, Globalization (www.imf.org/external/np/ib/ 2000)

${ }^{16}$ Nanang P. Mugasejati, Kritik Globalisasi dan Neoliberalisme, (Yogyakarta: Fisipol UGM, 2006), 2.

${ }^{17} \mathrm{H}$. Sander, "Multilateralism, Regionalism and Globalization: The Challenges to the World Trading System", World Trade after the Uruguay Round:
}

multinasional. ${ }^{16}$ Implikasi proses ini, terjadilah proses liberalisasi, perdagangan bebas yang berorientasi keluar, standar luar (lisensi), privatisasi investasi, import dan masuknya perusahaan-perusahaan asing dengan aturan asing. ${ }^{17}$ Dibalik internasionalisasi dan liberalisasi di bidang ekonomi, ada proses universalisasi produkproduk dan budaya dunia. Dan yang sangat kuat dalam hal ini adalah negara-negara Barat. Karena itu, globalisasi juga adalah proses amerikanisasi atau westernisasi, dan de-culturization local dan nasional. ${ }^{18}$ Budaya agama lokal dan kontekstual pun berubah menjadi budaya agama/gereja amarika dan barat. Selain itu terjadi juga proses deteritorialisasi atau super teritorialisasi sehingga yang terjadi adalah proses hilangnya jarak dan batas teritori (wilayah) antar Negara, ${ }^{19}$ yang bisa berakibat pada terjadi ketegangan yang berlanjut pada peperangan.

\section{Dimensi-dimensi Globalisasi}

Trand globalisasi dikarakteristikkan dengan (1) Economic globalization, ditandai meningkatnya international trade,

Prospects and Policy Options for the Twenty First Century, edited by H. Sander, (London: Routlegde, 1996), p. 27

${ }^{18}$ P.J. Taylor, "Ization of the World: Americanization, Modernization and Globalization" Demystifying Globalization, edited by C. Hay and D. Marsh, (Basingstoke: Macmillan, 2000).

${ }^{19}$ Nanang Pamuji Mugasejati, Kritik Globalisasi dan Neoliberalisme ..., 4. 
international finance dan multinational corporations. ${ }^{20}$ (2) Cultural globalization, yang ditandai dengan multiculturalism melalui perfilman, travel/tourism, produk makanan, model dan budaya pop, ungkapanungkapan asing (mamamia, amigos dan adios "shalom"). Specialization telah ditinggalkan menjadi globalisasi budaya (homogenisasi). (3). Political globalization, terbukanya politik Negara manapun, yang bergandengan dengan kepentingan ekonomi, meningkatnya perhatian pada hukum internasional. ${ }^{21}$ (4) Emigrational globalization terjadi perpindahan penduduk besar-besaran dan secara cepat lintas kota dan negara. (5) Technological globalization, khususnya teknologi komunikasi dan informatika yang dianggap sebagai komoditi yang merajai semua komoditi lain. Karena itu, tidak ada satu sendi kehidupan dunia yang luput dari proses globalisasi, sehingga menghasilkan tekanan yang berat di semua sektor kehidupan, seperti yang dikemukakan lebih jauh berikut ini.

\section{Globalisasi adalah Tekanan Global Dari dan $\underline{\text { Ke Segala Arah }}$}

Globalisasi menekan ke banyak arah, sehingga tidak ada yang luput dari

\footnotetext{
${ }^{20}$ David Held, Anthony McGrew, Globalization ...7-8.

${ }^{21}$ Research Globalization, (www.polity.co.uk/global/executive.htm)

22"Kami menegaskan sebenarnya globalisasi merupakan ancaman serius kepada orang-orang Islam,
}

pengaruhnya. Pertama, globalisasi bergerak dari atas ke bawah yaitu tidak bisa menghindari asimilasi budaya dan berdampak pada memudarnya nasionalitas. Kedua, globalisasi bergerak ke samping kiri, berupa tekanan internasional kelompok tertentu (etnis, agama tertentu). Ketiga, globaliasi bergerak ke samping kanan, yakni dengan menciptakan zona-zona ekonomi multi negara yang tergabung dalam bisnis multinasional. Keempat, globaliasi bergerak ke atas, berupa tuntutan global dalam persaingan pasar bebas, dimana individu atau perusahaan atau Negara yang kuat berperan sebagai "tuan" atas yang lain. Kelima, globalisasi bergerak ke luar karena adanya penyimpangan yang menyebabkan bangkitnya kaum proteksionis nasionalis dan agamawi, menjadi anti-globalist yang memandang globalisasi sebagai ancaman yang sangat serius bagi iman agamanya, ${ }^{22}$ cenderung menyalahkan globalisasi. ${ }^{23}$ dan menyerang pro-globalists yang lebih banyak berhubungan dengan kekristenan.

\section{$\underline{\text { Peran Hamba Tuhan sebagai Aktor Utama }}$ Globalisasi}

Globalisasi adalah suatu gerakan yang mendunia, arus besar dan kenyang

\footnotetext{
...mengikis kepercayaan umat Islam kepada pegangan, nilai budaya dan tradisi hidup Islam”, S.M. Mohamad Idris, Koordinator Third World Netwok"

23 Eric Hiariej, "Gerakan Anti Kapitalisme Global", ...97.
} 
menghanyutkan telah menenggelamkan banyak kapal organisasi (perusahaan). Jangankan jemaat yang terhanyut, bukan tidak sedikit pemimpin agama (hamba Tuhan) pun terhanyut dan tenggelam seperti yang nampak pada cara pikir, cara hidup, cara kerja, cara bisnis, cara pelayanan yang lebih serupa dunia dari pada serupa Kristus.

Globalisasi telah membuat banyak orang dan organisasi tertentu menjadi rakus dan ganas tiada ampun. Yang kuat semakin kuat, dan yang lemah semakin lemah. Yang kaya semakin kaya, dan yang miskin semakin miskin. Yang berdaya semakin jaya, dan yang tidak berdaya semakin diperdaya.

Lalu, di manakah hamba Tuhan, orang-orang utusan Tuhan sekarang ini berada? Apakah hamba Tuhan hanya bersembunyi di area spesialisasinya sebagai gembala, pengajar, misionaris, penginjil, atau spesialisasinya sebagai ahli teologia, ahli Perjanjian Lama, ahli Perjanjian Baru, ahli misiologi, dan lain sebagainya? Apakah hamba Tuhan hanya "menjadi aktor" (eksklusif) dalam komunitas Kristen dan mengabaikan komunitas yang ada di luar Kristen? Tentu, bukan ini maksud dan kehendak Tuhan mengutus hamba-hambaNya! Tuhan menghendaki hamba-hambaNya menjadi aktor utama globalisasi berdasarkan eksposisi Efesus 5:15-21, sebagai penjabaran dari amanat globalisasi dalam Kejadian 1:28, yaitu amanat untuk "menaklukkan dan berkuasa" atas semua ciptaan yang lain.

Rasul Paulus menulis surat Efesus ini dalam konteks jemaat yang sedang menghadapi arus globalisasi di kota Efesus sebagai metropolitan dan kota perdagangan, dan kota dengan masyarakat yang majemuk etnis, budaya dan agamanya, seperti konteks Indonesia.

\section{Dasar Teologis, Peran sebagai Aktor Utama Globalisasi}

Peran sebagai aktor utama globalisasi didasarkan pada keyakinan Paulus sebagai utusan Tuhan. Utusan atau rasul (Ef. 1:1a) adalah orang yang dimiliki oleh Pengutus. Hamba Tuhan adalah utusan Tuhan dan milik Tuhan. Tuhan mengutus "hamba-Nya" (seutuhnya) bukan ke dalam gereja, melainkan ke dalam dunia (seutuhnya) melalui gereja sehingga menjadi hamba Tuhan untuk semua orang (global) dalam upaya untuk memberitakan Firman-Nya (seutuhnya) baik melalui perkataan maupun melalui perbuatan (seutuhnya).

Menjadi utusan Tuhan bukan berdasarkan pada kehendak diri sendiri, bukan juga berdasarkan pada kehendak banyak orang (demokrasi) melainkan berdasarkan kehendak Allah (Ef. 1:1). Dengan demikian, sebagai utusan-Nya, maka kehendak Tuhanlah yang akan dilakukan dan diperjuangkan serta dijadikan tujuan (goal) 
semua tugasnya. Tidak ada yang lebih hebat dari pada kehendak Allah. Kehendak globalisasi berada di bawah kehendak Allah. Inilah dasar yang kuat dari seorang hamba Tuhan berperan sebagai aktor utama globalisasi.

\section{$\underline{\text { Kompetensi Hamba Tuhan sebagai Aktor }}$ Utama Globalisasi}

Yang kuatlah yang akan mampu berperan sebagai aktor utama globalisasi. Yang kuat ialah yang berkompetensi khusus (bukan umum). Yang berkompetensi khusus adalah orang-orang yang disebut Rasul Paulus sebagai orang-orang bijak atau arif (Ef. 5:15). Hamba Tuhan yang berkomptensi khusus adalah hamba Tuhan yang arif atau bijak, yaitu hamba Tuhan yang suka meniru “gaya hidup" pemimpin/ pengusaha. Hamba Tuhan yang tidak suka mengikuti cara hidup, cara kerja dan cara pelayanan yang berorientasi pada keuntungan (berkat), melainkan berorientasi kepada kehendak Allah yang mengutusnya.

Salah satu kompetensi khusus hamba Tuhan yang arif (bijaksana) adalah dalam hal mempergunakan waktu. Rasul Paulus menegaskan "pergunakan waktu yang ada" (redeem your time). Hamba Tuhan yang berkompetensi khusus tidak akan memberi peluang sedikit pun kepada yang jahat (karena hari-hari ini adalah jahat - Ef. 5:16). Peran utama hamba Tuhan sebagai aktor utama globalisasi, yaitu memberitakan Firman. Itu artinya menggunakan waktu yang ada.

\section{Berteologia Integratif sebagai Aktor Utama $\underline{\text { Globalisasi }}$}

Globalisasi secara mendasar adalah gerakan cara berpikir global (worldview) yang dipicu dan dipacu oleh para ilmuan melalui ilmu pengetahuan dan teknologi, namun mereka pun tidak mampu mengontrol gerakan tersebut, mereka justru terbawa arus gerakan globalisasi. Karena itu, bukan ilmu pengetahuan dan teknologi yang bisa menjadi aktor utama globalisasi, melainkan teologia melalui peran teolog. Rasul Paulus menegaskan supaya orang percaya berteologia, yaitu "mengerti kehendak Tuhan" (Ef. 5:17b). Orang yang tidak berteologia adalah orang bodoh (Ef. 5:17a). Hamba Tuhan yang tidak serius berteologia, tidak serius menjadi hamba Tuhan! Orang yang bertheologia akan mampu mengontrol arus deras globalisasi. Dengan teologia (mengerti kehendak Tuhan) orang tidak akan mabuk oleh anggur (IPTEK) dan globalisasi, karena dengan berteologia maka Roh Kudus akan memampukan dalam mengendalikan arus globalisasi yang berawal dari kemampuan mengendalikan diri sendiri (penuh Roh Kudus - Ef. 5:18b). 
Beribadah dan Berdampak secara Rohani (Membangun dan Mengayakan)

Globalisasi ditandai dengan dinamisnya kehidupan, sibuknya arus lalu lintas dan komunikasi dan ramainya orang bekerja. Bumi ini seperti tidak pernah tertidur. Demikian juga dengan hamba Tuhan di globalisasi ini sangat sibuk melayani (berkhotbah) sehingga tidak lagi sempat beribadah dan menjadi hamba Tuhan yang miskin rohani. Memang setiap minggu mereka melayani (berkhotbah) mungkin sampai lima kali setiap hari minggu, namun hanya datang ke gereja untuk berkhotbah (melayani) bukan beribadah. Hanya datang menjelang waktu khotbah dimulai, dan langsung pulang setelah khotbah usai. Hamba Tuhan yang berperan sebagai aktor utama globalisasi, yaitu yang suka beribadah, yang hidup berdampak secara rohani kepada dunia sekitarnya secara mengglobal.

Orang yang hidup berdampak rohani secara global adalah orang yang sama dengan yang digambarkan oleh Rasul Paulus dalam tulisannya, yaitu: "Berkata-katalah seorang kepada yang lain dalam Mazmur, kidung puji-pujian dan nyanyian rohani. Bernyanyi dan bersoraklah bagi Tuhan dengan segenap hati. Ucaplah syukur senantiasa atas segala sesuatu dalam nama Tuhan kita Yesus Kristus kepada Allah dan Bapa kita" (Ef. 5:19-21). Hidup yang berdampak global, adalah hidup yang penuh kemenangan (senantiasa bersyukur) dan hidup dalam kerendahan hati (rendahkanlah dirimu).

\section{KESIMPULAN}

Mengakhiri artikel ini, penulis mengajak pembaca untuk memulai hidup dan pelayanan dengan berperan sebagai hamba Tuhan, aktor utama globalisasi. (1) Memberi diri untuk diproses menjadi aktor utama globalisasi melalui pendidikan holistic (global) sehingga mengalami kompetensi holistic (global), berkarakter Kristus dan berkompetensi global. (2) Memahami dan menguasai konteks berpikir (global pattern of thinking) dan pola hidup yang tergambar pada gaya hidup yang mengglobal (global life style), dan mengalami kebenaran tekstual (eternal and universal truth) dalam frame theologia holistic (integrative theology). (3) Memengaruhi dunia secara global melalui "globalisasi" atau "teknologisasi" peran sebagai aktor utama globalisasi melalui mengimplementasikan

"integrative theology" (holistic) dalam semua sektor dan sendi kehidupan. Akhirnya, Mengarahkan semuanya kepada kehendak yang mutlak dari Pencipta, Pemilik, Pemelihara, Pengontrol serta Penyudah dunia dengan gerakan Globalisasinya.

Mengawali keempat langkah di atas ini, tidak ada cara yang pantas, selain memulainya dengan memohon kepada Pencipta, Pemilik, Pemelihara, Pengontrol 
serta Penyudah sejarah dunia, termasuk penyudah gerakan globalisasi, supaya Ia memberikan "air mata" kepada umat-Nya masing-masing, bukan karena umat-Nya cengeng, melainkan karena "sangat berbeban" dengan keadaan manusia di planet bumi ini, dan berkata "masalah seluruh umat di dunia, adalah masalahku", karena itu, "inilah aku, utuslah aku" berperan sebagai aktor utama globalisasi melalui tugas memberitakan Injil (theology integrative).

\section{DAFTAR PUSTAKA}

\section{$\underline{B u k u}$}

Alex Araujo, "Globalization and World Evangelism”, Evangelical Dictionary of World Mission, edited by A. Scott Moreau. Grand Rapids: Baker Books, 2000.

Archer, M. Globalization, Knowledge and Society. London: 1990.

Dockery, David S. The Challenge of Postmodern: An Evangelical Engagement. Grand Rapids: Baker Academic, 2001.

El Fisgon, Menghadapi Globalisasi. Tangerang: PT Cipta Lintas Wacana, 2004.

Franke, John R. The Character of Theology: A Postconservative Evangelical Approach. Grand Rapids: Baker Academis, 2005.

H, Sander. "Multilateralism, Regionalism and Globalization: The Challenges to the World Trading System", World Trade after the Uruguay Round: Prospects and Policy Options for the Twenty First Century, edited by H. Sander. London: Routlegde, 1996.
Mugasejati, Nanang P. Kritik Globalisasi dan Neoliberalisme. Yogyakarta: Fisipol UGM, 2006.

Penner, Myron B. Christianity and the Postmodern Turn. Grand Rapids: Brazos Press, 2005.

Robertson, R. Globalization. London: Sage, 1992.

Vanhoozer, Kevin J. Postmodern Theology. Cambridge, UK: Cambridge University Press, 2003.

\section{$\underline{\text { Internet }}$}

Held, David dan Anthony McGrew, Globalization (www.imf.org/external/np/ib/ 2000)

IMF, World Economic Outlook, May 1997 (www.imf.org/external/np/ib/2000)

Khairuddin Tadjuddin, Globalisasi (www.selaras.com).

Power relations are deeply inscribed in the very process of globalization". Researching Globalization (www.polity.co.uk/ global/executive/htm). 